\title{
Harry Kalven and Kenneth Karst in the Supreme Court Review: Reflections After Fifty Years
}

\section{Citation}

Mark Tushnet, Harry Kalven and Kenneth Karst in the Supreme Court Review: Reflections After Fifty Years, 2010 Sup. Ct. Rev. 35 (2010).

\section{Permanent link}

http://nrs.harvard.edu/urn-3:HUL.InstRepos:10880570

\section{Terms of Use}

This article was downloaded from Harvard University's DASH repository, and is made available under the terms and conditions applicable to Open Access Policy Articles, as set forth at http:// nrs.harvard.edu/urn-3:HUL.InstRepos:dash.current.terms-of-use\#OAP

\section{Share Your Story}

The Harvard community has made this article openly available.

Please share how this access benefits you. Submit a story. 


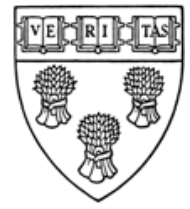

Harvard Law School

Public Law \& Legal Theory Working Paper Series

Paper No. 11-01

\title{
Harry Kalven and Kenneth Karst in the Supreme Court Review: Reflections After Fifty Years
}

\author{
Mark Tushnet \\ Harvard Law School
}

This paper can be downloaded without charge from the Social Science

Research Network (SSRN) electronic library. 
Harry Kalven and Kenneth Karst in the Supreme Court Review:

\section{Reflections After Fifty Years}

Mark Tushnet

Reading the articles by Harry Kalven and Kenneth Karst fifty years after their initial publication in the Supreme Court Review is invigorating and dispiriting. ${ }^{1}$ Invigorating, because it reminds a reader in an era of constitutional "theory" how much we can learn from incisive doctrinal analyses that worry Supreme Court opinions one way and another, trying to figure out what the decisions might mean rather than trying to evaluate them by invoking some large interpretive theory or trying to explain them by invoking concepts drawn from what we have come to call "other disciplines." Invigorating, too, because the articles show that the questions that scholars today regard as deep were already present, though sometimes submerged, in those articles. But dispiriting, because one wonders how much progress we actually have made in understanding constitutional law over the past fifty years. Perhaps we have merely been rephrasing in terms we find comforting the questions - and answers - offered by Kalven and Karst. ${ }^{2}$ And dispiriting, too, because Kalven and Karst write in a style simultaneously detached from and engaged with the Justices - that has been lost to us.

\footnotetext{
${ }^{1}$ Harry Kalven, Jr, The Metaphysics of the Law of Obscenity, 1960 Sup Ct Rev 1; Kenneth I Karst, Legislative Facts in Constitutional Litigation, 1960 Sup Ct Rev 75. ${ }^{2}$ I should note that I have the recurrent experience of reading older articles - forty or more years after publication - and being dismayed to learn that insights that I thought had been only recently hard-won were available much earlier. My dismay passes as I come to
} 
I Kalven on the Law of Obscenity

“The Metaphysics of the Law of Obscenity” examines in detail several thenrecent Supreme Court decisions. Time has rendered obsolete most of Kalven's specific arguments, but the way he addressed the decisions remains important. Perhaps the most significant feature of his article is its generosity of spirit. While criticizing each of them, Kalven indicates that every justice made valuable contributions to analyzing the problem of regulating obscenity within the Constitution, although no one solved it. Kalven is clearly sympathetic to the outcome reached by Justices Black and Douglas, though he is mildly skeptical about their doctrinal absolutism. He is attracted to Justice Frankfurter's balancing, but he worries that it is too unstructured. Overall, Kalven presents himself as a somewhat detached observer of the Court's work, yet somehow in dialogue with it. He ends his article with a long paragraph about "the extraordinary difficulty" of the Court's task. ${ }^{3}$ The task was difficult because of the "freighted” topic of obscenity, because obscenity law raises core issues about freedom of speech, and because "they perform

appreciate that each generation of scholars probably has to discover basic truths for itself. The observation usually attributed to Mark Twain comes to mind: "When I was a boy of fourteen, my father was so ignorant I could hardly stand to have the old man around. But when I got to be twenty-one, I was astonished at how much the old man had learned in seven years.” I take this to express an important truth about the relation between experience and knowledge understood as justified true belief.

${ }^{3}$ Kalven at 45 (cited in note ---). 
their roles in an institutional context" of extreme complexity. ${ }^{4}$ His final words are, "The rest of us are fortunate indeed that our job is so much easier and less responsible.”5

A Analyzing the Opinions

After a brief discussion of Butler v Michigan, ${ }^{6}$ Kalven turned to the opinions in Roth $v$ United States and Alberts $v$ California. ${ }^{7}$ Roth was a prosecution by the federal government for violating a federal statute prohibiting sending obscene publications through the mails. Alberts was a state prosecution for publishing obscene materials. Kalven observed that Justice Brennan’s opinion for the Court “decisively and unequivocally disposed of doubts as to constitutionality, but "by a route which nearly bypassed all the perplexities” of the problem. ${ }^{8}$ The reason was that Justice Brennan treated the question before the Court as whether any regulation of obscenity could pass constitutional muster; as we would put it today, the grant of review was limited to a facial challenge to obscenity statutes. Kalven criticized Justice Brennan’s apparent assumption that obscenity laws could be unconstitutional only if "under the First Amendment no utterances can be prohibited.”9 In light of United States $v$ Stevens, which appears to have held that the categories of "low value" speech are to be determined by a strictly historical

\footnotetext{
${ }^{4}$ Ibid.

${ }^{5}$ Ibid.

6352 US 380 (1957).

7 354 US 476 (1957).

${ }^{8}$ Kalven at 8 (cited in note ---).

${ }^{9}$ Id at 9 .
} 
test without searching for some underlying principle distinguishing low-value from higher-value speech, ${ }^{10}$ we might say today that Justice Brennan was arguing at least implicitly that there was no principled way to distinguish between obscene utterances and other "low value” utterances. Put in those terms, Justice Brennan’s position is more defensible than Kalven suggested.

Kalven then addressed the two-tier theory directly, which he concluded was an approach that "may have unhappy repercussions on the protection of free speech generally."11 He thought it "difficult to accept as doctrine” even though "it afforded the Court a statesmanlike way around a dilemma.”12 After a long paragraph setting out the doctrinal structure of the two-tier theory, Kalven said that the correct question about lowvalue speech such as obscenity was, "[W]hat is the social utility of excessively candid and explicit discussions of sex?”13 The next sentence moved to what Kalven clearly believed was the heart of the problem, the "mixed utterance,” in which such “excessive”

${ }^{10}$ United States v Stevens, 559 US ---, ---, 130 SCt 1577, 1586 (2010) (“Our decisions ... cannot be taken as establishing a freewheeling authority to declare new categories of speech outside the scope of the First Amendment. Maybe there are some categories of speech that have been historically unprotected, but have not yet been specifically identified or discussed as such in our case law.... We need not foreclose the future recognition of such additional categories to reject the Government's highly manipulable balancing test as a means of identifying them.”).

${ }^{11}$ Kalven at 17 (cited in note ---).

${ }^{12}$ Id at 10.

${ }^{13}$ Id at 12. 
candor is "integral" to some "serious view."14 A solution to that problem would lie in the definition of obscenity, a definition that Justice Brennan's formulation of the issue before the Court avoided. $^{15}$

But, Kalven continued, defining obscenity with reference to its worthlessness exposed "a difficulty” with traditional defenses of fee speech. ${ }^{16}$ Focusing on how speech contributes to democratic self-governance does not "help much" in explaining why works of imaginative literature and art were covered by the First Amendment: “The people do not need novels or dramas or paintings or poems because they will be called upon to vote. Art and belles-lettres do not deal in such ideas...."17 Conceding the obvious, that the

14 Ibid.

${ }^{15}$ Kalven suggested a definition quite similar to the one on which the Court eventually settled before giving up on the definitional task in Miller v California, 413 US 15 (1973): “Obscenity must be so defined as to save any serious, complex piece of writing or art.” Id at 13. Given the importance of Kalven's article, one cannot tell without examining the Justices’ papers - which I have not - whether Kalven’s formulation influenced the Court's, whether the Court invented its formulation independently, or whether the formulation flowed ineluctably from the Court's logic so that anyone addressing the question of definition would reach the same answer. Justice Brennan provides the only citations in Supreme Court opinions to Kalven’s article, in Ginsberg v United States, 390 US 629, 637 n 5 (1968), and Paris Adult Theatres I v Slaton, 413 US 49, 97 (1973)

(Brennan. J, dissenting).

${ }^{16}$ Kalven at 15 (cited in note ---).

${ }^{17}$ Id at 16. 
Court would place art works under the First Amendment's coverage, ${ }^{18}$ Kalven found “a hiatus in our basic free-speech theory.”19 In my view the gap has not yet been filled and, despite Kalven’s prescience, remains largely unnoticed and discussed only rarely. ${ }^{20}$

Acknowledging that Justice Brennan’s opinion “made several major contributions to the law," Kalven still found the opinion "unsatisfactory” because it endorsed the twotier theory and “appeared to find no difficulties” in addressing the problem. ${ }^{21}$ He turned to the other opinions to show how Justice Brennan’s opinion was “unpersuasive” and to illuminate the "full complexity of the issue.",2 The "difficulties” that Justice Brennan “so carefully muted exploded” in Justice Douglas’s dissent, which rejected the two-tier theory in favor of “a single unified doctrine of free speech” that rejected judicial attention to "the social utility of speech." 23 Rather, doctrine should permit regulation only if “there be evidence of clear danger of action resulting from” any verbal - and, if Kalven was right about art, any symbolic - expression. ${ }^{24}$

${ }^{18}$ Cf Hurley v Irish-American Gay, Lesbian and Bisexual Group of Boston, 515 US 557, 569 (1995) (describing the “painting of Jackson Pollock [and] the music of Arnold Schoenberg” as “unquestionably shielded” by the First Amendment).

${ }^{19}$ Kalven at 16 (cited in note ---).

${ }^{20}$ For a recent treatment, see R George Wright, What Counts as "Speech" in the First

Place?: Determining the Scope of the Free Speech Clause, 37 Pepp L Rev 1217 (2010).

${ }^{21}$ Kalven at 17 (cited in note ---).

22 Ibid.

${ }^{23}$ Id at $18-19$.

${ }^{24}$ Id at 19. 
Kalven devoted nearly as much space to Justice Harlan’s “complex and interesting” opinion as he did to Justice Brennan’s. He praised Justice Harlan’s perception, not inconsistent with anything in Justice Brennan's opinion, that the question of whether a particular item was obscene was a question of constitutional fact, not to be conclusively determined by juries or trial judges as fact-finders but subject to “independent review” by appellate courts and ultimately the Supreme Court. ${ }^{25}$ And, he had some striking observations about Justice Harlan’s effort to distinguish between the tests to be applied to regulation at the national and state levels. Going beyond the obvious points about federalism, Kalven was struck by the fact that the only free-speech cases in which some justices had suggested such a distinction were cases invoking the two-tier theory to place some material outside the First Amendment's coverage: "Is this just a coincidence or is there a relationship?,” he asked. ${ }^{26}$ He hinted at an answer, mentioning that an unrestrictive rule on the national level would impose a ban on "the entire country,” and the local interest in regulation in restriction was stronger (less “attenuated,” in Kalven’s words) than the national government’s. ${ }^{27}$ Earlier Kalven suggested that Justice Brennan’s opinion might be statesmanlike even though doctrinally unsatisfactory; the same point is implicit in Kalven’s treatment of Justice Harlan’s

\footnotetext{
${ }^{25}$ Id at 20-21. Kalven was right, although the experience of giving materials an independent review was so distasteful that in the end the Court reformulated the test for obscenity in a way that ultimately led to the law's effective demise. See text accompanying notes --- below.

${ }^{26}$ Id at 23.

${ }^{27}$ Id at 24.
} 
opinion, which, though “elegan[t]," was "full of unresolved difficulties," not unlike Justice Brennan's. ${ }^{28}$ In the end, the opinions gave us “more free-speech doctrine than can be used sensibly," an observation bolstered by Justice Harlan's effort to distinguish between the terms used in the federal statute and the state one, which "reveal a capacity to find satisfying distinctions that seem too fine for the ordinary mind.”29

Criticizing Justices Brennan and especially Harlan for erecting an unhelpfully complex doctrinal structure, Kalven was plainly sympathetic with Justice Douglas's approach, although in a later passage he referred to "doctrinaire liberalism," which his readers would certainly take as a reference to the constitutional jurisprudence of Justices Douglas and Black. Kalven’s sympathy for Justice Douglas's free-speech absolutism suggests a revision in a widespread view about the legal academy and the Court in the 1950s - that academics derided Justices Black and Douglas for their First Amendment absolutism and strongly preferred some form of judicial balancing of competing considerations. Discussing Justice Frankfurter's concurring opinion in Kingsley Pictures Corp $v$ Regents, in which the Court unanimously invalidated New York's system for licensing films, Kalven observed that Frankfurter's opinion had "familiar echoes of his earlier opinions on free speech” in calling for "careful balancing.”30 Kalven observed, "However one may feel about the evils of doctrinaire liberalism against which Mr. Justice

\footnotetext{
${ }^{28}$ Id at 25.

${ }^{29}$ Id at 25, 26.

${ }^{30}$ Id at 31.
} 
Frankfurter has so valiantly fought, one cannot, I think, be happy with this opinion.”31 The other opinions in the case had "made valid general points" that Frankfurter did not deal with: "In his desire to avoid broad libertarian generalizations, Mr. Justice Frankfurter generalized too little.” ${ }^{32}$ Here Kalven set out the agenda for at least categorical balancing or even absolute (libertarian?) rules, an issue that continues to bedevil First Amendment theory as shown by the Stevens decision. ${ }^{33}$ In Kalven’s words, “The preoccupation with balancing ..., although it steers clear of the doctrinaire, comes precariously close to the opposite evil of the intuitive, particularized judgment which offers no guidance for the future.” ${ }^{34}$ This “opened up basic issues transcending the problems of obscenity," the tension between "clear statement[s] of ruling principles” and “a particularized balancing that is inevitably personal.”35

${ }^{31}$ Ibid. See also id at 38 (drawing "the moral” that "there are serious weaknesses in Mr. Justice Frankfurter's favorite doctrine of judicial economy” from his analysis of Justice Frankfurter's criticism of the majority in Smith v California, 361 US 147 (1959), for failing to provide adequate guidance to legislative drafters).

${ }^{32}$ Id at $31,32$.

${ }^{33}$ See discussion at note --- above.

${ }^{34}$ Kalven at 32 (cited in note ---).

${ }^{35}$ Id at 34. Recurring disagreements between Justice Breyer and some of his colleagues appear to reproduce the tension Kalven identified, but Justice Breyer’s “balancing” is more structured than the one Kalven attributed to Justice Frankfurter. For additional discussion, see text at notes --- below. 
Kalven’s attention to "basic issues” recurred in his briefer discussions of the Court's other obscenity cases. In Smith v California, Justice Frankfurter concurred in the result because the trial judge has excluded expert testimony on whether a work's dominant appeal is to "prurient interest measured by prevailing community standards."36 Again “echo[ing]” Justices Douglas and Black, Kalven "suggest[ed] that heavy reliance on expert testimony to objectivize the obscenity judgment indicates once again how powerful is the argument that that obscenity is a fatally ambiguous concept.” ${ }^{37}$ Kalven wondered why the jury was not the best measure of community standards; one might add that Frankfurter's endorsement of expert judgment on what might appear to be fundamentally normative questions is of a piece with his commitment to the Progressive vision of administrative agencies. $^{38}$

Kalven's article uses the word "metaphysics” in its title, but he offered no extended explanation for that use. ${ }^{39}$ My reading of the title makes it compatible with

\footnotetext{
${ }^{36}$ Kalven at 39 (cited in note ---), discussing Smith v California, 361 US 147 (1959). ${ }^{37}$ Ibid.

${ }^{38}$ For a discussion of Frankfurter's view on administrative agencies and expertise, see Mark Tushnet, Administrative Law in the 1930s: The Supreme Court's Accommodation of Progressive Legal Theory, --- Duke L J (forthcoming 2011). ${ }^{39}$ Indeed, unless I (and the search function in Hein OnLine) missed it, neither the word nor any variant occurs in the article's text or footnotes. Whether those searches were complete is largely irrelevant to my point here, which is that Kalven did not explain his use of the term in any detail. I am reliably informed that the Review's editor chose the title, which probably explains why the article itself does not explain its own title.
} 
Kalven's attitude of detached sympathy. The problem of obscenity law is metaphysical in the serious sense that it raises fundamental questions about what constitutional law is and can do. It is also metaphysical in the somewhat pejorative sense that the Court's discussions are perhaps inevitably detached from the reality with which it and the law of obscenity - and, who knows?, perhaps all constitutional law - must deal. ${ }^{40}$

\section{B Contemporary Problems}

For all practical purposes the law of obscenity has disappeared from view. After a decade and a half of grappling with the problem, the Court adopted a test for identifying obscenity that made "contemporary community standards" determinative. ${ }^{41}$ First videotapes, then DVDs, and finally the Web made "hard core" obscenity readily available. Community standards changed to the point where prosecutors found it essentially pointless to pursue obscenity charges against sexually explicit material depicting adults. The law of obscenity remains one of the better vehicles for explicating

${ }^{40}$ The pejorative sense comes through in an extended quotation Kalven offered from a brief filed by Thurman Arnold in the Supreme Court, in which Arnold argues, as Kalven put it, that "any fool can quickly recognize hard-core pornography, but it is a fatal trap for judicial decorum and judicial sanity to attempt thereafter to write an opinion explaining why.” Kalven at 43 (cited in note ---) (quotation from Arnold at 44). Kalven added a note expressing skepticism that it is so easy to identify hard-core pornography: "One suspects that the touchstone is more likely to be the social status of the publisher than the content of the item.” Id at 43 n 129.

${ }^{41}$ Miller v California, 413 US 15 (1973). 
the two-tier theory of free speech, but even for purely pedagogical purposes the subject has become problematic. Aside from the difficulty of discussing obscene material in classes where students may be either unfamiliar with the material or familiar with it but embarrassed about saying so, the subject has been complicated by efforts to regulate the different category of pornography. Though those efforts appear to have peaked in the 1990s, they remain interesting conceptually. They provide a vehicle for exploring the possibility of conflicts between constitutional rights or values (free speech and equality) and the idea some speech regulations might be defensible as legislative efforts to increase the dissemination of speech overall.

The “conflict of rights” problem requires us to distinguish between constitutional rights and constitutional values; the “maximizing speech” problem requires us to worry about the relation between quantity (of speech) and distribution (of speakers). Kalven’s analysis of obscenity law does not help us in thinking about these newer arguments, at least directly. The "rights/values” problem raises questions about the state action doctrine and whether we have a constitution of merely negative liberties or one of positive rights as well. ${ }^{42}$ The "quantity/distribution” problem raises questions about the foundations of democracy as a system of government resting on individual autonomy,

${ }^{42}$ Legislative regulation of pornography promotes a constitutional value of equality, but the source of the inequality lies not in the government decisions that are the focus of a state-action oriented account of equality but rather in private decisions. In a constitution of positive rights, the government might be thought to have a duty to address the latter source of inequality. For a discussion, see Frank Michelman, Conceptions of Democracy in American Constitutional Argument, 56 Tenn L Rev 291 (1989). 
more openly addressed in the Supreme Court's campaign finance decisions. None of those topics appears in Kalven's article. But, it is perhaps worth noting that in both areas the Court and commentators are often more conclusory than analytical. Addressing the “quantity/distribution” question, for example, the Court curtly observed, "the concept that government may restrict the speech of some elements of our society in order to enhance the relative voice of others is wholly foreign to the First Amendment," ${ }^{43}$ without noting that the argument really is that regulation can increase the net amount of speech disseminated while incidentally altering its distribution among speakers rather than "in order to" alter that distribution. In thinking about the modern versions of the problems Kalven dealt with, we might do well to remember not the specifics of his doctrinal analysis but the generous spirit in which he undertook it.

\section{Karst on Legislative Facts}

“Legislative Facts in Constitutional Adjudication” took off from the observation that many Supreme Court decisions rested on the Justices’ assessment of facts - not necessarily the facts of the case at hand, but facts about the way things worked in the society at large. He worried that the Justices’ assessments too often rested on assumptions that might not stand up to close examination. The problem has not

\footnotetext{
${ }^{43}$ Buckley v Valeo, 424 US 1, 48-49 (1976). The sentiment has been repeated. See, eg, Davis v Federal Election Comm’n, 554 US 724, 753 (2008); Citizens United v. Federal Election Comm’n, --- US ---, ---, 130 SCt 876, 904 (2010).
} 
disappeared. ${ }^{44}$ In the Citizens United decision, the Court had to address the claim that independent expenditures by corporations that expressly endorsed or opposed identified candidates would lead voters to believe that their votes mattered less than the money spent by corporations. Responding to that claim Justice Kennedy wrote, "The appearance of influence or access ... will not cause the electorate to lose faith in our democracy."45 This certainly looks like a factual claim. Justice Kennedy supported it by offering legal arguments, the import of which is that it would not be reasonable for people to lose faith in democracy in response to such expenditures - perhaps true, but unresponsive to the apparent factual claim. ${ }^{46}$ Perhaps reflecting an optimism about the role of reason in

${ }^{44}$ For a recent overview, see Timothy Zick, Constitutional Empiricism: Quasi-Neutral Principles and Constitutional Truths, 82 N C L Rev 115 (2003). ${ }^{45}$ Citizens United v Federal Elections Comm’n, --- US ---, ---, 130 SCt 876, 910 (2010). For another example, see Purcell v. Gonzalez, 549 US 1, 3 (2006) ("Voter fraud drives honest citizens out of the democratic process and breeds distrust of our government. Voters who fear their legitimate votes will be outweighed by fraudulent ones will feel disenfranchised.”), discussed in Richard L Hasen, The Untimely Death of Bush v Gore, 60 Stan L Rev 1, 35 (2007). (The examples should not be taken to suggest that I believe that election law cases distinctively produce unsupported reliance on empirical claims.) 46 The remainder of the Citizens United paragraph reads, “By definition, an independent expenditure is political speech presented to the electorate that is not coordinated with a candidate. The fact that a corporation, or any other speaker, is willing to spend money to try to persuade voters presupposes that the people have the ultimate influence over elected officials. This is inconsistent with any suggestion that the electorate will refuse 
adjudication, Karst offered a series of sensible suggestions for making the Court more familiar with the social facts on which informed constitutional adjudication should rest. Before he did so, though, he developed a description of an adjudicatory approach that retains vitality.

\section{A Analyzing the Opinions}

Karst began by describing the once-famous "mud flaps" case, where the Court invalidated a state law requiring the use of curved mud flaps on trucks passing through the state. ${ }^{47}$ As Karst put it, "everyone connected with the case” understood that the "ultimate question" was, "How much more effective must the new guard be to justify a cost of $\$ 30$ per truck ... in light of the fact that other states permit the use of the old-style guards?”48 Justice Douglas's opinion for the Court characterized the problem as involving "questions of degree," ${ }^{49}$ which led Karst to reflect on the "dispute between the so-called balancers and absolutists." ${ }^{50}$ For Karst, denying that balancing was inevitable was "to strike at the heart of the rule of law." 51

“"to take part in democratic governance”" because of additional political speech made by a corporation or any other speaker.” --- US at ---, 130 SCt at 910.

${ }^{47}$ Bibb v Navajo Freight Lines, 359 US 520 (1959).

${ }^{48}$ Karst at 78 (cited in note ---).

${ }^{49} 359$ US at 530.

${ }^{50}$ Karst at 78 (cited in note ---).

${ }^{51}$ Id at 80. 
Responding to the argument that balancing was impossible because the values at stake were incommensurable, ${ }^{52}$ Karst launched into his first major analytic effort, aimed at providing a structure for conducting the balancing. He used Breithaupt $v$ Abram to focus his discussion. ${ }^{53}$ There the Court upheld a conviction based on the administration of a blood alcohol test to a driver rendered unconscious in an automobile collision. Karst asked what the questions of legislative fact were in that case. "First of all, how serious is the invasion of the accused's person?"54 We might note immediately that characterizing "seriousness of invasion of person" as a question of fact at all is not the obviously correct course. Karst's meaning is clear, though: We can array intrusions on the person along a single dimension, with something like taking fingerprints near one end and performing a risky and non-lifesaving operation to remove a bullet near the other. ${ }^{55}$ In performing the required balancing, we will initially ask where on this continuum the intrusion is.

\footnotetext{
${ }^{52}$ Cf Bendix Autolite Corp v Midwesco Enterprises, Inc, 486 US 888, 897 (1988) (Scalia, J, concurring in the judgment) (“This process is ordinarily called 'balancing,' but the scale analogy is not really appropriate, since the interests on both sides are incommensurate. It is more like judging whether a particular line is longer than a particular rock is heavy.”). (Eccles 1:9: “What has been will be again, what has been done will be done again; there is nothing new under the sun.”).

53352 US 432 (1957).

${ }^{54}$ Karst at 82 (cited in note ---).

${ }^{55}$ For the bullet-extraction example, see Winston v Lee, 470 US 753 (1985).
} 
Next, "What is the purpose of this invasion of the body?"56 This looks like an ordinary adjudicative fact: Did the police take the blood sample because they were investigating a crime or because one of them had a perverted interest in acquiring blood for his collection? ${ }^{57}$ Karst, though, saw a question of legislative fact lurking: Assuming that the police are engaged in an investigation, "how effectively will the blood test fulfill" the investigative purpose?”58 Perhaps the tests for determining blood-alcohol levels are quite bad, or though good in principle are routinely done quite badly by the laboratories the police use. But, Karst observed, the tests were "almost universally well-regarded for their reliability," and "there is widespread scientific agreement” that people with high blood-alcohol levels are physically impaired. ${ }^{59}$

That is not the end of the inquiry, though. Perhaps there is "some alternative way of achieving those same good purposes without causing the same impact on the individual's liberty." ${ }^{60}$ Karst catalogued some possibilities - getting evidence about how much liquor the driver had consumed, testimony about smelling liquor on the driver's breath - but observed that they might not be as effective in proving high blood-alcohol

${ }^{56}$ Karst at 82 (cited in note ---).

57 The allusion here is to the television series “Dexter" (Showtime, since 2006), based on the novel, Jeff Lindsay, I'm attaching some information for authors of the Routledge Handbook on Constitutional Law. Please let me know if you hDarkly Creaming Dexter (Doubleday, 2004).

${ }^{58}$ Karst at 82 (cited in note ---).

59 Ibid.

${ }^{60}$ Id at 83. 
levels as the blood test was. Suppose, though, that the police had available a less intrusive technology, perhaps one that could determine blood-alcohol levels from beads of sweat (or could be induced to encourage the development of such a technology were they barred from taking the driver’s blood)? ${ }^{61}$

Karst then generalized. The question for balancers will take a common form. "How much will this regulation advance the chosen governmental objective?,” taking into account the possibility of "partial success," and "How much more will this regulation advance the objective than some other regulation which might interfere less with constitutionally protected interests?” In addition, “How much will freedom ... be restricted by this regulation," again considering the probabilities of complete and only partial effectiveness, and "How much more restrictive is this regulation than some other regulation which might achieve the same objective?”62 Again Karst characterized all these as "questions of fact." 63

${ }^{61}$ Karst used the example of a “'drunkometer’ balloon.” Ibid. Karst repeated this type of analysis in his discussion of Talley v California, 362 US 60 (1960), where the Court invalidated a city ordinance prohibiting the distribution of handbills that lacked the names and addresses of the authors. Karst at 92-93 (cited in note ---) (asking, inter alia, how often have anonymous handbills be used in frauds, how many complaints had there been to the Better Business Bureau, and were there reasons for handbill distributors to be concerned for their safety were their names to appear on the handbills). To the same effect, see his discussion of Huron Portland Cement Co v Detroit, 362 US 440 (1960), at 96 (providing a similar list of questions).

${ }^{62}$ Id at 84 . 
Today this is almost instantly recognizable as the kind of structured proportionality inquiry used by constitutional courts around the world. ${ }^{64}$ If structure is all one is seeking, Karst's or some similar formulation might be entirely adequate. But, we have learned that describing the problem as one involving the assessment of facts, even legislative facts, will not in the end solve the incommensurability problem. The reason is easiest to see in the stage known elsewhere as the application of the test of "proportionality as such" and in Karst's formulation as the determination of the governmental objective. Karst's analysis of Breithaupt helps identify the difficulty. The government's primary objective is determining accurately the degree of the driver's impairment, and there may be other less intrusive technologies that do as good a job as the blood test in measuring that. The government has other objectives, though, including a budget constraint: It wants to determine impairment as accurately as it can within some budget for doing so. And, again generalizing, it will almost always be the case that there

${ }^{63}$ Ibid.

${ }^{64}$ For one widely followed formulation, see R v Oakes, [1986] 1 SCR 103 (Sup Ct Canada), ๆ 70: "First, the measures adopted must be carefully designed to achieve the objective in question. They must not be arbitrary, unfair or based on irrational considerations. In short, they must be rationally connected to the objective. Second, the means, even if rationally connected to the objective in this first sense, should impair 'as little as possible' the right or freedom in question. Third, there must be a proportionality between the effects of the measures which are responsible for limiting the Charter right or freedom, and the objective which has been identified as of 'sufficient importance."” 
is a tradeoff between the primary objective and other objectives when considering alternative means, one more intrusive than the other. ${ }^{65}$

A section explaining that judicial attention to legislative facts would not be inconsistent with a presumption of constitutionality alluded to differences in the trial records in two First Amendment cases, observing that in one "the Court ... was faced with a record almost devoid of consideration of the legislative facts, and with briefs of counsel which only partly filled the void. ${ }^{, 66}$ Karst used those differences to introduce a discussion of what could be done to improve the Supreme Court's ability to determine legislative facts.

Legislative facts, according to Karst, involved "prediction and probability," complex matters for which judges "need[] expert help.”67 Brandeis briefs could do something, but trials at which issues of legislative fact were explored were better because trial judges could sort out and evaluate the complexities. Karst devoted several pages to exploring the conditions under which expert testimony and cross-examination were likely to be better than expert memoranda (and counter-memoranda) in putting the trial judge in a position to determine the legislative facts. Then Karst turned to the ability of judges to

${ }^{65}$ The point is well-known in the literature on proportionality and of course in parallel contexts such as purposive statutory interpretation. For one particularly clear exposition, see Mark Elliott, "Proportionality and Deference: The Importance of a Structured Approach,” in Effective Judicial Review: A Cornerstone of Good Governance 264, 27780 (Christopher Forsyth et al, eds 2010).

${ }^{66}$ Karst at 91 (cited in note ---).

${ }^{67}$ Id at $99-100$. 
evaluate the enhanced records they would have before them. He urged conscientious efforts, but could offer little beyond that other than a reiteration of the "traditional American faith in the value of education.”"68 His approach, he wrote, "envisages judges who take a more aggressive role than that which is customary, judges who do not leave to the parties the determination of the issues to be litigated but who actively promote the exploration of issues which the parties might be content to leave untouched.”69 Again, Karst did not explore whether judges in the real world could do that to some reasonably acceptable level of quality. He did observe that because "the presumption of constitutionality is weakest ... [where] there is the least difference between the competence of lay judgment and that expert judgment," the presumption could do some work - although precisely because experts and judges could draw on the same general information where the presumption of constitutionality was weak, we can wonder whether enhancing the records makes much difference in this category of cases.

\section{B Contemporary Problems}

Some of Karst's proposals for reform are the product of the times. He was committed to the Progressive vision of government and its problems, opening his article with a reference to "the rapidity of contemporary social, technological, political, and economic changes,” and in his proposals for reform expressing a confidence in the ability of experts to provide the information needed for courts to address the problems posed by

\footnotetext{
${ }^{68}$ Id at 112.

${ }^{69}$ Id at 109.
} 
those changes. ${ }^{70}$ Some of the proposals seem in retrospect a bit naïve. In part the difficulty is that Karst may have identified primarily failures of advocacy, cases in which lawyers failed to use techniques that were available to them. If such failures are a problem, one would think that reforms lie in the direction of improving attorney quality rather than in providing lawyers unable effectively to use the tools at hand with an additional set of tools, unless there is some reason to think that the new tools are easier for lawyers of unchanged quality to use. ${ }^{71}$

Consider the idea of building better trial records on factual matters. Powell $v$ Texas involved a constitutional challenge to then-widespread policies of charging homeless alcoholics with public drunkenness. ${ }^{72}$ At trial in a Texas municipal court Powell's lawyer argued that the charge was a status offense imposing liability on those who because of their medical condition could not control their appearance in public. He supported the argument with testimony from a medical doctor to the effect that alcoholism was a disease. The trial judge made "findings of fact" about alcoholism, including that chronic alcoholics do "not appear in public by [their] own volition."73 The Supreme Court rejected Powell’s claim, with Justice Marshall observing that "the record in this case is utterly inadequate to permit the sort of informed and responsible adjudication which alone can support the announcement of an important and wide-

\footnotetext{
${ }^{70}$ Id at 76.

${ }^{71}$ Karst referred to "failure[s]" by members of the bar, partly attributable to "judges who do not demand that counsel fulfill their responsibilities.” Id at 99.

72392 US 514 (1968).

${ }^{73}$ Quoted in id at 521.
} 
ranging new constitutional principle,” and that “[t]he trial hardly reflects the sharp legal and evidentiary clash between fully prepared adversary litigants which is traditionally expected in major constitutional cases."

Perhaps Powell's lawyer did not go far enough in the direction Karst urged. Yet, we can wonder about the effectiveness of trials as venues for exploring the legislative facts on which Karst focused. More extensive trials, of course, but also at much greater expense, with costs borne at least initially by lawyers with other cases to handle. ${ }^{75}$ From that perspective, we might be impressed with how much an ordinary lawyer in a Texas municipal court did to build a record on the nature and effects of alcoholism, and take that to indicate some deeper flaw in Karst's effort to improve the Court's ability to assess legislative facts by developing better records at trial. Supplementing trials with amicus briefs and the like generates information provided by competing - and hired - experts,

\footnotetext{
${ }^{74}$ Id at $521-22$.

${ }^{75}$ Karst alluded to the problem in commenting that it might not be "worth the very considerable extra expense and delay” occasioned by remanding a criminal case for further factual development, but he suggested even so that it "may be appropriate” to "put [a criminal defendant] through the wringer a second time ... when large interests are represented as parties or sponsors of the litigation,” for example, the context suggests, when the National Association for the Advancement of Colored People or the American Civil Liberties Union was involved. Karst at 95-96 (cited in note ---). See also id at 101 (noting that "testimony tends to be more costly to the parties").
} 
with "axes to grind," as Karst put it, ${ }^{76}$ probably leaving the justices no better informed about the facts than they would have been without the additional information. ${ }^{77}$

Justice Marshall’s observation in Powell that “there is no agreement among members of the medical profession about what it means to say that 'alcoholism' is a 'disease „"78 suggests another, probably larger difficulty. Often legislative facts will be open to reasonable contestation. ${ }^{79}$ One expert will say that tires will explode under normal operating conditions at a rate of $\mathrm{X}$ blow-outs per mile if they are inflated to $\mathrm{Y}$ pounds per square inch, another will say that at Y pounds the blow-out rate will be Z . Surveys will have to be interpreted, and experts will raise reasonable questions about the effects of the questions’ precise phrasing on reported outcomes. Statisticians will question the model specification used to produce epidemiological estimates about some phenomenon important to the factual basis for legislation. ${ }^{80}$ We can get reasonably

\footnotetext{
${ }^{76}$ Id at 105.

${ }^{77} \mathrm{Cf}$ id at 96 (referring to “doubts about the ability of experts to improve on the justices' own efforts”).

${ }^{78}$ Id at 522.

${ }^{79}$ For examples from Supreme Court decisions, see San Antonio Ind Sch Dist v Rodriguez, 411 US 1, 26-27 (1973) (raising questions about what the statistical material submitted in the lower courts showed about relevant constitutional questions); McCleskey v Kemp, 481 US 279, 312 (1987) (“At most, the Baldus study indicates a discrepancy that appear to correlate with race”) (emphasis added).

${ }^{80}$ For an amusing list of all-purpose objections to empirical studies, see George Stigler, The Conference Handbook, 85 J Pol Econ 441 (1977).
} 
precise estimates of such facts as the rate at which the moon orbits the earth - certainly good enough to support legislation. But, of course, facts of that sort are almost never legislative facts in Karst's sense. Where more contestable facts are involved, which is to say with respect to almost every statute, an approach to constitutional adjudication that makes choices among such facts important seems misguided.

A more general way of putting this is that legislative "facts" might not really be facts of the sort scientists discover and epistemologists describe. Here the recent trial in California’s federal gay-marriage case may be exemplary. The district judge heard extensive testimony and made extensive findings of fact about whether individuals choose their sexual orientation, about whether the availability of same-sex marriage will affect the stability of opposite-sex marriage, and more. ${ }^{81}$ There is nothing wrong with calling these facts, but one need not be a post-modernist skeptic to think that they are qualitatively different from facts like the rate at which the moon orbits the earth.

There is, I suggest, a better way of thinking about the legislative facts on which Karst focused. Some of those facts are like the ones physical scientists report, but others are not. They are ways in which people in a scientifically oriented society articulate their competing visions of how a good (or decent, or well-ordered) society operates. Justice Kennedy’s seemingly factual assertions about the relation between campaign finance and the American people’s confidence in our political system fit this description. I believe not claims about the way the world is though stated in those terms, but claims about the

${ }^{81}$ Perry v Schwarzenegger, 704 FSupp 2d 921 (ND Cal 2010). 
way the world ought to be. ${ }^{82}$ And, Karst's proposed reforms would not provide the justices much help in figuring out the constitutional questions they face by providing them with the "facts" on which their judgments should rest.

The second theme in Karst's article was structured balancing, a topic that Justice Breyer has addressed recently. In District of Columbia v Heller Justice Breyer supplemented Justice Stevens's account of the original meaning of the Second Amendment with a detailed examination of whether the challenged restriction on handgun possession in the home was proportional to the problems the District was attempting to address. ${ }^{83}$ As noted above, courts around the world have used doctrines of proportionality as well. Scholars have begun to explore whether "it" is a unitary doctrine,

${ }^{82}$ Kennedy, Distributive and Paternalist Motives in Contract and Tort Law, with Special Reference to Compulsory Terms and Unequal Bargaining Power, 41 Md L Rev 563, 603 (1982) ("the move to efficiency transposes a conflict between groups in civil society from the level of a dispute about justice and truth to a dispute about facts - about probably unknowable social science data that no one will ever actually try to collect but which provides ample room for fanciful hypotheses.”), offers a more tempered version of this suggestion. Kennedy suggests that the inevitable ambiguities in the facts conceded to be relevant leave space for a judge acting in good faith to see as "established" those facts that are compatible with his or her vision of the world, which Kennedy calls "ideology." ${ }^{83} 554$ US 570, ---, 128 SCt 2783, 2852 (2008) (Breyer, J, dissenting) (enumerating cases in which the Court has "applied” proportionality analysis). Justice Breyer elaborated on his approach in Stephen Breyer, Making Our Democracy Work: A Judge’s View (2010). 
a "universal rule of law," as one Canadian scholar puts it, ${ }^{84}$ or whether a common language of proportionality and even a seemingly common analytic structure conceal the kinds of variations in legal culture that occur in nearly every comparative study.

Taking Justice Breyer’s opinion in Heller as their starting point, Moshe CohenEliya and Iddo Porat distinguish between what they call "intrinsic" and "bounded" balancing. ${ }^{85}$ The former, characteristic of German constitutional law, "expresses values of compromise, mediation, and pluralism," and "is tied to an organic conception of the state, under which all organs trust one another and cooperate to realize common values that express the spirit of the nation." ${ }^{\text {"I6 }}$ It is not "a pragmatic enterprise involving some sort of cost-benefit analysis," but rather attempts to "optimize[] the constitutional value order. ${ }^{87}$ In contrast, Cohen-Eliya and Porat argue, balancing in US constitutional law

${ }^{84}$ David M. Beatty, The Ultimate Rule of Law (2004).

${ }^{85}$ Moshe Cohen-Eliya \& Iddo Porat, The Hidden Foreign Law Debate in Heller: The Proportionality Approach in American Constitutional Law, 46 San Diego L Rev 367 (2009). For a more general treatment of proportionality analysis in a problem of comparative methodology, see Jacco Bomhoff, Balancing, the Global and the Local: Judicial Balancing as a Problematic Topic in Comparative (Constitutional) Law, 31 Hastings Int’l \& Comp L Rev 555 (2008).

${ }^{86}$ Cohen-Eliya \& Porat at 388 (cited in note ---).

${ }^{87}$ Id at 393, 394. The reference to the "constitutional value order" is to the decision of the German constitutional court in the Lüth case, 7 BVerfGe 198 (1958), partially translated in Donald Kommers, The Constitutional Jurisprudence of the Federal Republic of Germany 361 (2d ed 1997), whose holding that the German Basic Law enacts an 
accommodates "the suspicion-based American approach to the state,” with a "residual and instrumental role” within bounds set by the dominant theory of rights as trumps. ${ }^{88}$ It is instrumental and pragmatic rather than "idealistic and formalistic.” 89 Certainly Justice Breyer thinks of himself as a pragmatist, as Cohen-Eliya and Porat would expect.

The use of non-US materials in US constitutional interpretation has of course been quite controversial, but comparisons can be illuminating even if - or perhaps because - they are not used as the basis for interpreting the Constitution. The reappearance of discussions of balancing, now labeled proportionality, provides scholars with opportunities to explore again the territory Karst went over, and in particular to examine how there might be a distinctively American form of structured balancing.

\section{Conclusion}

None of what I have said so far means that the articles are without flaws that later scholarship helps identify. Central to Kalven's article, for example, is the observation that "the evil of arousing revulsion in adults ... is simply too trivial a predicate for constitutional regulation.”90 Earlier, discussing Justice Harlan’s approach to the problem

“objective order of values” has become the foundation of the German constitutional law of individual rights. The decision

${ }^{88}$ Cohen-Eliya \& Porat at 396, 399.

${ }^{89}$ Id at 399.

${ }^{90}$ Kalven at 42 (cited in note ---). Although the words are ambiguous, I take “constitutional regulation” to mean, not "regulation by the Constitution,” but "statutory regulation that survives constitutional challenge.” For confirmation of that interpretation, 
of regulation of obscenity, Kalven quoted Harlan's use of “the familiar” standard, that a legislature’s judgment “not be 'irrational,"” in connection with Harlan’s treatment of the claim that consumption of obscenity might induce "obnoxious" sexual conduct. ${ }^{91}$ Today we would properly not accept the judgment of even as sensible a person as Kalven that a specified "evil” was "too trivial.” We would ask whether the legislature's judgment that the evil was worth public regulation was reasonable. And, we would worry about the status of the claim that we can assess a judgment about moral evil - "arousing revulsion" - with criteria of rationality. We might ask whether it is enough that there be a reasonable basis for thinking that moral evils can be determined through rational analysis and then that there be a reasonable basis, from within that way of thinking, for concluding that “arousing revulsion” is a moral evil. Kalven’s assessment that the evil was "too trivial” might reflect his judgment that, from some unspecified perspective, the legislative judgment is unreasonable or irrational, but he was so sensible that he did not see that there might be other perspectives that legislatures were entitled to take.

Similarly, Kalven used a familiar trope of raising questions left unresolved by the decisions they analyze. For example, Justice Frankfurter was "silent” about "valid general points" made by his colleagues: "Is thematic obscenity constitutionally subject to state control? ... Is the ... statute too vague?"92 We know that this sort of "twenty

see id at 4 ("Arousing disgust and revulsion in a voluntary audience seems an impossibly trivial base for making speech a crime.”)

${ }^{91}$ Id at 24 (quoting Roth v United States, 354 US 476, 501-02 (1957) (Harlan, J, concurring)).

${ }^{92}$ Id at 31. 
questions" criticism is close to vacuous because it is always available and never really

cogent. ${ }^{93}$ It is always available because no decision can foreclose litigation exploring the contours of the doctrine it articulates, if only because attempts to do so can always be dismissed as dicta unnecessary for the disposition of the case before the Court. And, it is never really cogent because a decision takes on meaning only as later courts use it. ${ }^{94}$

"Well, nobody’s perfect," $" 95$ but Kalven and Karst come close. Their articles stand up extraordinarily well after fifty years. Absolutism versus categorical balancing versus ad hoc balancing: We still worry about these, now calling them rules and standards or proportionality and unguided discretion, and it unclear that we know much more about

${ }^{93}$ For the best recent example of the "twenty questions" approach, see Caperton v AT Massey Coal Co, --- US ---, ---, 129 SCt 2252, 2269-72 (2009) (Roberts CJ, dissenting) (listing forty questions unresolved by the majority's holding).

${ }^{94}$ For the most sophisticated exposition of this proposition of which I am aware, see Deutsch, Precedent and Adjudication, 83 Yale L J 1553 (1974). As I understand it, Chief Justice Rehnquist's approach to writing decisions rested on a similar view. His opinions were spare in the extreme, describing the case facts, listing the precedents thought relevant, and stating that the precedents supported the conclusion announced. Rehnquist eschewed extended analysis of how one got from the precedents to the result because, I believe, he understood that no matter what he said, later courts would pour content into the result without regard to the proferred reasoning.

${ }^{95}$ Quotation from “Some Like It Hot” (United Artists, 1959), final line. 
the problems than when Kalven and Karst illuminated them. ${ }^{96}$ Kalven's article ended with a footnote offering “an inventory” of four judicial roles in obscenity cases: "urbane resignation” exemplified by Learned Hand, “irreverent amusement” exemplified by Jerome Frank, “uncompromising concern with free speech,” as with Justices Black and Douglas, and the role taken by "the responsible man of affairs who feels that there are limits to what the public will tolerate a court's saying ... exemplified by most members of the Court."97 Kalven was too good a writer to say so, but this inventory covers a great deal, perhaps all, of constitutional law, and scholars as well as judges. In his article Kalven took the first role, of urbane detachment, with a hint of the second. Yet, I think it reasonably clear that he thought the fourth, that of the "responsible man of affairs," was the one our judges should take. As the final line of his article showed, he believed that the judges' job is different from that of the scholar, who has the freedom to be irresponsible. And, if scholarship has its virtues, so does responsibility. We should admire, Kalven suggested, those who take on important public responsibilities, and not be too harsh in evaluating their work with urbane detachment and irreverent amusement. Even Kalven’s critical comments are generally offered in subdued tones: An argument

\footnotetext{
${ }^{96}$ We talk about the problems in different terms because of the rise of "constitutional theory,” but whether the terminology (for example, of decision costs and error costs in connection with the rules/standards or absolutism/balancing discussions) has added anything significant to our knowledge seems to me an open question.

${ }^{97}$ Kalven at 45 n 132 (cited in note ---).
} 
"is curious," it "is unfortunate that the collision of complex analyses ... could not have been carried to more explicit resolution.”98

A few years later Kalven's law school colleague and the founding editor of the Supreme Court Review Philip Kurland made what might have seemed the same point about the burdens of public responsibility in the concluding paragraph of his Foreword to the Harvard Law Review's annual issue on the Supreme Court: "It behooves any critic of the Court's performance to close on a note reminiscent of the wall plaque of frontier times: 'Don’t shoot the piano player. He’s doing his best.",99 The tone, though, was different and much sharper, hardly sympathetic to the constraints the "responsible man of affairs” necessarily finds himself under and properly accommodates. For, Kurland's final sentences were, "It is still possible ... to wish that he would stick to the piano and not try to be a one-man band. It is too much to ask that he take piano lessons.”100

Kurland's tone foreshadowed a change in the rhetoric in which academic discourse about the Supreme Court was conducted that, I suggest, came about because of the rise of "constitutional theory," understood as the enterprise of identifying the single best method of constitutional interpretation that simultaneously licensed judges to find some statutes unconstitutional and constrained them from doing so to advance their mere “policy” preferences. Perhaps it was not inevitable, but the rise of constitutional theory conduced to characterization of those who disagreed with the writer's preferred

\footnotetext{
${ }^{98}$ Id at 9, 26.

${ }^{99}$ Philip Kurland, Foreword: Equal in Origin and Equal in Title to the Legislative and Executive Branches of the Government, 78 Harv L Rev 143, 196 (1964). 100 Ibid.
} 
constitutional theory as either fools or knaves: fools, because they lacked the intellectual capacity to understand the compelling logic of the arguments supporting the theory, or knaves, because, knowing that the theory was the best one available, they willfully disregarded it in the service of their personal projects. ${ }^{101}$ The ideas that the constitutional questions the Supreme Court deals with are genuinely difficult and that the Justices, people of varying intellectual ability, can reasonably disagree over, for example, the strength of the originalist evidence for and against the positions taken by the majority and dissent in District of Columbia v Heller are almost completely absent from today's constitutional discourse - and those who try to advance those ideas are dismissed as naïve (fools) or as pursuing a concealed political agenda (knaves).

The issues Kalven and Karst discussed remain with us, but their sensibility has been lost. It would, I think, be good to retrieve it, but I wonder whether that is possible. An intellectually ambitious scholar today who is the same age as Kalven and Karst were when they wrote their articles would be well-advised - and I am sure is advised - to avoid doing "mere doctrinal work." 102 Kalven and Karst were engaged with doctrine far

${ }^{101}$ I do not exempt myself from participation in the discourse of foolishness and knavery. For the most notorious example, see Mark Tushnet, Dia-Tribe, 78 Mich L Rev 694 (1980). I am older and, I hope, wiser now. (For that reason, I refrain from providing examples of the discourse of foolishness and knavery, but I do note that it is not confined to the academy but infects the Supreme Court itself.)

${ }^{102}$ Been there, done that myself. 
more deeply than today's scholars are. ${ }^{103}$ For obvious structural reasons those with dual degrees in law and some other discipline are unlikely to, and in my experience do not, achieve the heights that Kalven and Karst reached. ${ }^{104}$ But, only by reaching those heights can one truly appreciate the difficulties faced by "responsible men of affairs," and

${ }^{103}$ An example is found in the care Kalven took to distinguish between direct regulation of obscenity - penalties imposed on its dissemination - and indirect regulation through rules that induce self-interested actors to "steer wide[] of the forbidden zone," as Justice Brennan put it in a related context. Speiser v Randall, 357 US 513, 526 (1958). Drawing on his wide knowledge in the field, Kalven pointed out that lower courts, with seeming approval from the Supreme Court, "steadfastly rejected” the argument that indirect regulation was to be assessed using the doctrines employed to deal with direct regulations. Kalven at 36-37 (cited in note ---).

${ }^{104}$ Briefly: Although reasonably smart, well-trained lawyers can do doctrinal analysis to a decent level of sophistication, doing doctrinal analysis at the highest level is difficult indeed, requiring a fair amount of intellectual facility and a wide grasp of doctrine from many fields. Dividing one's intellectual effort between acquiring facility in doctrinal analysis and achieving distinction in another discipline means that one will be unable to reach the heights of doctrinal analysis. And, on the other side, in every "other" discipline of which I am aware, the field “other discipline of law” (legal history, sociology of law, economics of law, and the like) is marginal to the discipline as a whole, which means that the most able graduate students will be drawn to the fields at the discipline's core, leaving the subfield dealing with law populated by perfectly able but not truly exceptional students. (There are of course exceptions, quite rare in my experience.) 
thereby achieve the detached sympathy that Kalven and Karst had for the Supreme Court and its work. That few scholars today have the capacity to do so is unfortunate. 